\title{
NOISE-STIMULATION EFFECTS ON PREGNANT RATS AND ITS FETUSES
}

\author{
By \\ KENZO OKUDA \\ From the Department of Oto-rhino-laryngology, Osaka City University \\ Medical School (Director: Prof. K. Yamamoto)
}

This experiment was performed in order to study the effect of noise given to pregnant rats and its fetuses.

White noise of 100 phone was given pregnant rats for 6 hours daily from the 1st day to the 10th day of pregnancy (A), from the 11 th day to the 20 th day (B), and from the 1 st day to the 20th day (C).

As stress index to pregnant rats, blood eosinophils were calculated before and after noise-stimulation.

The fetuses were examined macroscopically and microscopically on the 21 th day.
The results obtained were as follows:

1) In A group, the weight of fetuses were decreased and the mortality of fetuses were increased.

2) In B group, the effects of noise-stimulation were scarcely observed.

3) In C group, blood eosinophils were remarkably decreased, and growth inhibiting of fetuses and high mortality of fetuses were observed.

4) In all groups, malformation of fetuses were not observed, but there is no denying the tetragenic activity for high mortality of fetuses in $\mathrm{C}$ group.

\section{騒音刺戟の弤娠母獣とその胎仔に 及ぼす影響について} 大阪市立大学医学部耳㸶喉科学教室 (主任: 山本整教授)

奥 毘 兼

緒言

近代文化の発達と共に，日常私達が騒音に接する機会 は非常に多くなつた。 そしてこの騥音は今日では, 大き な社会問題の1つとなり，種々の立場から興味深い研究 課題として取り上げられている，即ら医学的な分野で は，精神面において，騒音は Emotional stimuli とい われているように，情緒面に影響を及ぼし，聴取者に不 快感，焦燥感等を起さしぬることは周知の如くであり， 肉体面に扣いては，胃連動の排制，血糖の增加，リンパ 球の增加，好酸球の減少などの病的状態を萑起すること が明らか、されている。しかし今なお末解決の点が多い 現状である。

私達の教室に乱いても，騒音の人体に及ぼす影響につ
いて，諸種の面から研究を進めているが，今回私は騒音 が妊娠母獣に加はることによつて，その母獣に対するス トレス影響を，循環好酸球数を指標として検索し，さら． にその胎仔にはどのような影響を及ぼすがついて，摘 出胎仔を肉眼的に観察すると共に，その聴器について組 織学的に榆索を行つたので，得られた知見を報告する。

\section{実験方法}

(1) 実験 動物

実験動物としては，雌性ダイコクネズミ（雑系）体重 150〜200g のものを用い，これに健康な雄性ダイコクネ ズミを交配して翌朝噇内に精子を認めた場合を，娃娠第 1 日とした。飼料は 1 日につき，玄米約 $30 \mathrm{~g}$ ，魚粉 $0.5 \mathrm{~g}$ 及び野菜小量である。 


\section{(2) 実験方法}

i) 区 分

A 群……妊娠第1 日より第 10 日目まで騷音を聴取さ せる群

B 群……妊娠第 11 日より第 20 日目まで噍音を聴取さ せる群

C群……妊娠第1 日より第 20 日目で騒音を俧取させ る群

以上の各群に毎日 6 時間ずつ（午後 1 時より午後 7 時。 まで）100phon の白色騷音を聴取させた。対照群には， 騒音を聪取さ好ならた。

ii）実験装置

因 1 亿示方如く, Audio O.S.C. Amplifier, スピーカ 一、级び音響被曝箱を使用し，これを防音室におき，音 響被曝箱中の妪娠母獣に対しては，音響曝露量が不均等 にならぬように，騒音指示計にて確認した。

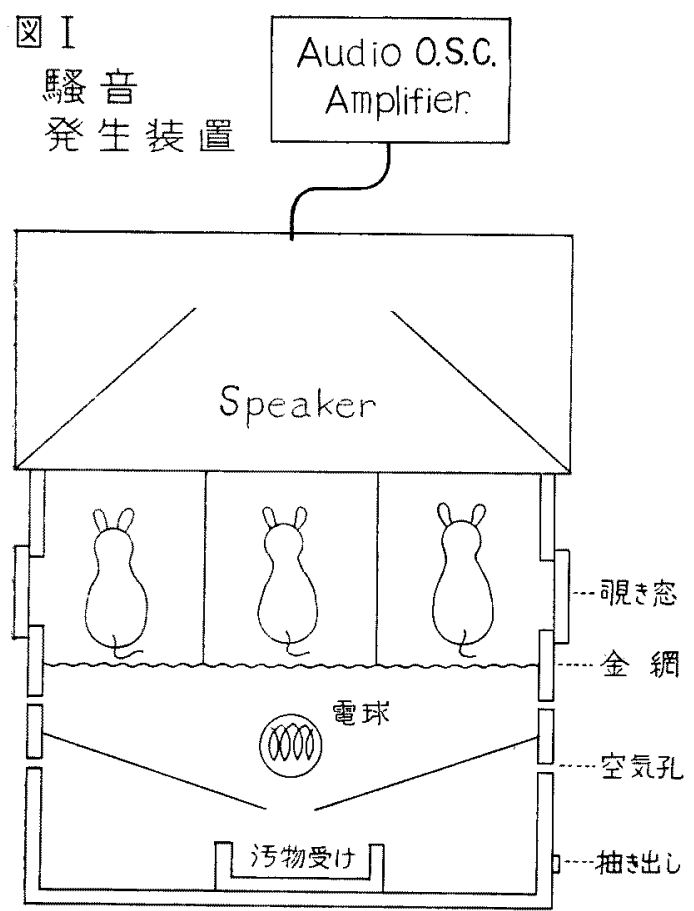

iii) 検 查

\section{A) 循環好酸球数}

母獣に及ぽすストレス指標として, 循罢好酸球数を測 定した。即ち妊娠母獣の眼静脈叢より採血した血液を， 白血球用メランジニールの0.5の目盛まで吸引し，次い で Hinkelmann 氏液を11まで吸引して，上く混和し
て染色し，計算した。な执計算盤としては，FuchsRosenthal 型のもの3 放を用い，その平均値を算出し， この数を 6.25 倍した. この值を $1 \mathrm{~mm}^{3}$ 中の好酸球数と する.

測定は各群共に，予定日数の騒音刺战開始直前及び終 了直後の 2 回に行つた.

な打好酸球数は，季節的变動が大であるといわれてい るため，本実験はダイコクネズミの交配し易い3月下旬 上り，5月上旬の間に行つた。

B) 肉眼的観察

異常后出に際して，母獣はしばしばこれを食べると いわれているので，分婏予定前日即ら胎生 21 日目に妊 娠母獣を開腹，胎仔を取り出すと共に，胎盤について胎 存吸収の有無を調へ，取り出した胎任について10倍脑 大鏡を使用して，眼，口蓋，四肢などの異常有無を钼察 し，ついで生存胎仔の体重を測定，さらに開腹して，各 䁍器の異常有無を調べた。

C) 組織学的観察

上記の観察後，胎仔は断頭，10\%ホルマリン固定，脱 水後，法に従いッェロイジン包埋を行つて，20 $\mu$ の連繶 切片を作成し，ヘマトキシリン・エオシンン重染色を行っ た.

な扮連続切片作成の際には，蝸牛軸を縦断せしめるた めに，上記材料を含む部分を立方体とし，上面及び下面 は硬口蓋をできるだけ水平にして連続切片とした。

\section{実験成績}

1) 循環好酸球数について

妊娠母獣に対するストレス指標として，循環好酸球数 を測定した結果は表 1 の如くであり，騒音刺㦸前後の減 少率を対照のそれと比較してみると，実駼 A, B 群江

表 1 循環好酸球数

\begin{tabular}{|c|c|c|c|c|c|}
\hline \multirow{2}{*}{ 群 } & \multirow{2}{*}{ 踽勗剌戟期間 } & \multirow{2}{*}{$\mid$} & 実 & 䍉 & \multirow{2}{*}{ 平均 } \\
\hline & & & 前 & 後 & \\
\hline \multirow[t]{2}{*}{ A } & $\begin{array}{l}\text { 㠰 } \\
\text { 第1日〜第10日娠 }\end{array}$ & 12 & 265 & 191 & $28.0 \%$ \\
\hline & 対 & 10 & 272 & 219 & $19.5 \%$ \\
\hline \multirow[t]{2}{*}{ B } & $\begin{array}{l}\text { 妊 } \\
\text { 第11日㢳 }\end{array}$ & 8 & 254 & 192 & $24.4 \%$ \\
\hline & 対 & 10 & 248 & 212 & $14.5 \%$ \\
\hline \multirow[t]{2}{*}{$\mathrm{C}$} & $\begin{array}{l}\text { 妊 } \\
\text { 第 } 1 \text { 日〜第20日娠 }\end{array}$ & 14 & 272 & 154 & $43.4 \%$ \\
\hline & 対 & 10 & 268 & 227 & $15.3 \%$ \\
\hline
\end{tabular}


哄約 10\% の差を示し，実験 C 群ではほぼ3 倍に近い 減少率が見られた。

2) 胎仔について

開腹㭙に殆んど吸収されている肧及び生存していない 胎仔は一括して死産とした.

表 2 亿示す如く，対照例では開腹時に全例において， 娃娠継続をみているが，実験 A 群では死産率は $24.3 \%$ 定し, 生存胎仔体重は対照のそれと比べて $0.5 \mathrm{~g}$ の減 少をみた. 実験 B 群では, 死産率は僅か $6.7 \%$ であり, 実験 C 群では, A 群の倍以上である 59.3\% の死産率 を示し, 生存胎仔の平均体重も $2.7 \mathrm{~g}$ で対照の $4.3 \mathrm{~g}$ 飞 比して，非常な減少がみられた。

A， B，C 群共異常仔の産出はみられなからた.

表 2

\begin{tabular}{|c|c|c|c|c|c|c|}
\hline 群 & $\begin{array}{l}\text { 騒 } \\
\text { 刺 戟 期 間 }\end{array}$ & $\begin{array}{|cc|}\mid \text { 害 } & \text { 験 } \\
\text { 獣数 }\end{array}$ & 死産数 & \begin{tabular}{|l|l} 
生 存 \\
胎仔数
\end{tabular} & $\mid$ & 死産率 \\
\hline A & 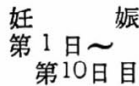 & 12 & 28 & 87 & $3.8 \mathrm{~g}$ & $24.3 \%$ \\
\hline B & $\begin{array}{l}\text { 妊 } \\
\text { 第11日辰 } \\
\text { 第20日目 }\end{array}$ & 8 & 5 & 70 & $4.2 \mathrm{~g}$ & $6.7 \%$ \\
\hline C & $\begin{array}{l}\text { 媢 } \\
\text { 第 } 1 \text { 娠 } \\
\text { 第20日日目 }\end{array}$ & 14 & 70 & 48 & $2.7 \mathrm{~g}$ & $59.3 \%$ \\
\hline 対照 & & 10 & 0 & 112 & $4.3 \mathrm{~g}$ & $0 \%$ \\
\hline
\end{tabular}

3) 組織学的所見について

外耳, 中耳では対照, 実験共に外耳道内腔から中耳腔 形成域に至るまで, 未だ胎生結合織をるつて充たされて おり, 耳小骨も軟骨組織より形成されていて, 三耳小骨 を区別できる程度である(図2). しかし実験 C 群では, その発育遅延の程度が目立つている(四3).

対照群の内耳は, 蝸牛では下部回転に打いては, 既に 鼓室階, 前庭階を区別でき, コルチ器原基の形成を認め る、しかしその細胞分化は未だ不充分である、螺旋靱 帯, 血管条形成域は共に間葉組織の性質が強く, 螺旋神 経節は認められる(図 4).

前庭部に佂いては, 平衡斑がみられ, 丘状に内リンパ 腔淌つて隆起し，そこに平衡砂を認める(図 5).

実験 A, B 群共に上記の所見と殆んど変らない。

実験 C 群では, 蝸牛においては前庭階, 鼓室階の区 別は未だなされず，蝸牛軸は幼弱結合織で充たされてお ク, コルチ器原基は, 2〜3 層の重畳した 円柱細胞をみ ろのみで, 螺旋靱帯, 血管条形成域共に未だ間葉組織の

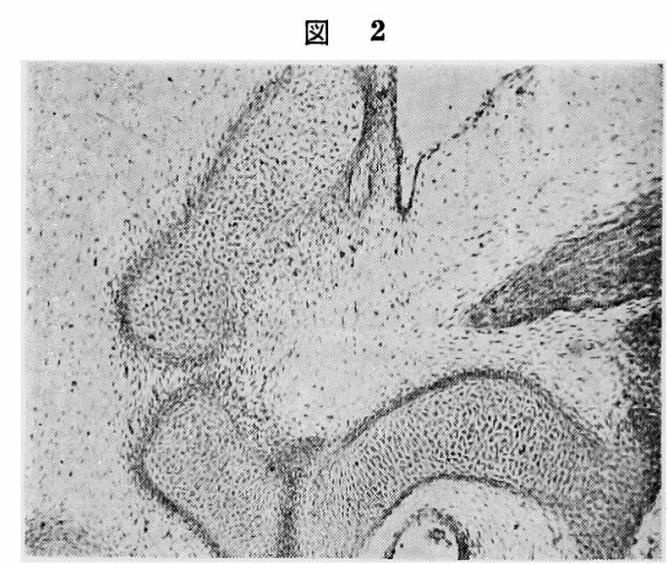

対照群に怙ける耳小骨原基 (H.E 染色 × 100)

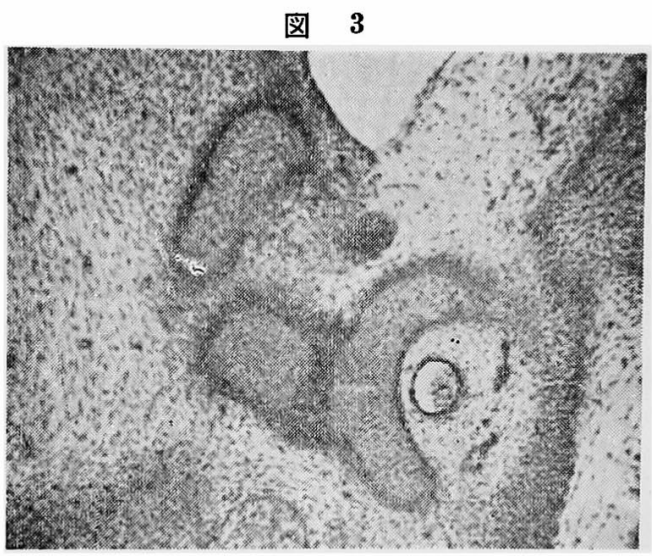

実験 C群における耳小骨原基 (H.E 染色×100)

图 4

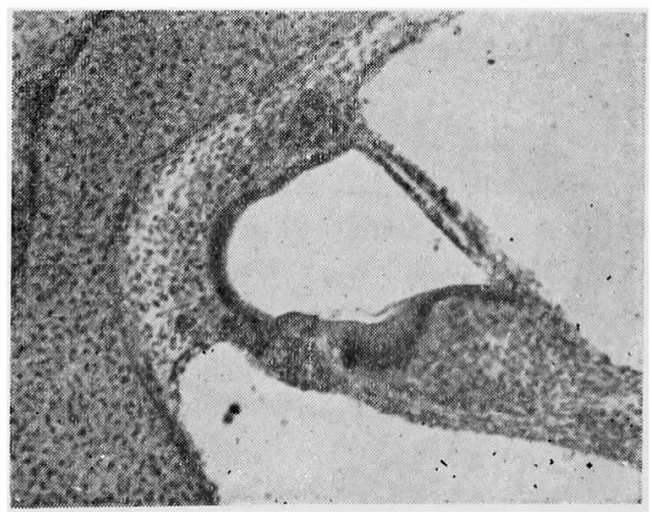

対照群に怙ける蝸牛殼管 $(H . E$ 染色 $\times 100)$ 
图 5

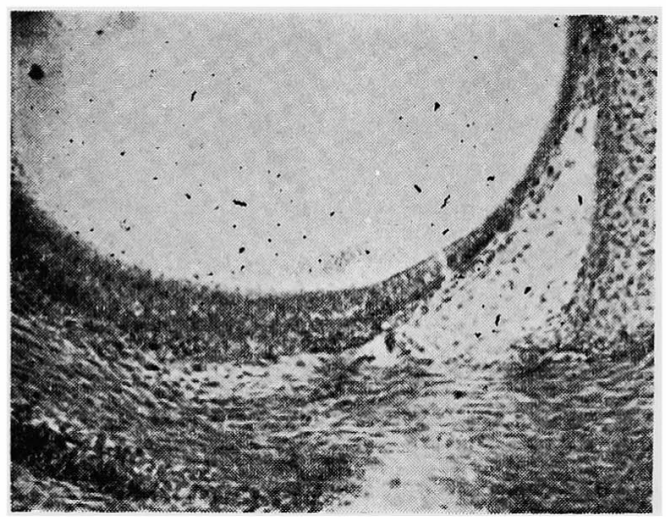

対照群に扣ける平衡斑及び平衡砂 $($ H.E 染色 $\times 100)$

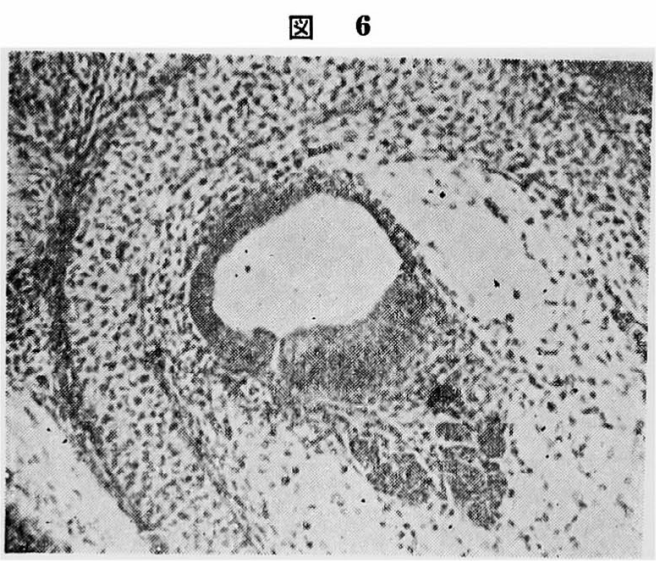

実験 C 群における蝸牛殼管 (H.E 染色 $\times 100)$

図 7

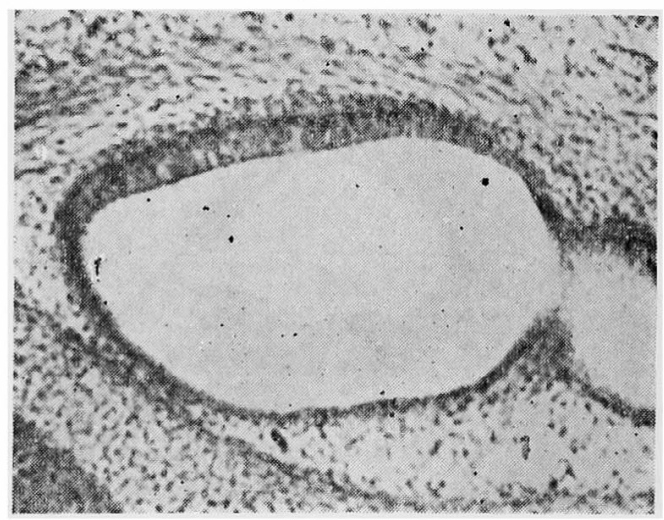

実験 C群における平衡斑 $(\mathrm{H} . \mathrm{E}$ 染色 $\times 100)$
性質が強い，塊状をなした螺旋神経節をみとめらる（四 6).

平衡斑では，感覚上皮は背が低く，平衡砂は認められ ない(図7).

\section{総括及び考按}

本研究は，騒音刺㦸が妊娠ダイコクネズミ及びその胎 仔に対して，どのような影響を及ぼすかを，明らかにせ んがために, 前者に対しては, 循環好酸球数を指標とし て て, 後者に対しては, 肉眼的及び 組織学的検索によつ て，対照母獣及び胎仔と比較，検討を行つたものであ る.

1. 循環好酸球数について

ヒト及び動物に音響刺㦸が加えられた場合，種々の反 応が出現する. 即ち聴器以外に現われる反応として内海 （1949）は，蛙に音響刺战を加えた場合，刺战中は呼吸 が緩徐，不規則になると述へ，真銅（1954）は種々の音 響刺战をモルモットに聴取させ，横隔膜電位と呼吸圧を 記録してその変化を述べ，McCann（1948）は，持続的 騒音刺㦸によつて起る血圧上昇には, 副腎皮質が関与し ていると思はれると報告している．中辻 (1958) は音響 刺㦸によつて, 一過性のアドレナリン分泌妄進をみと め, 沽田 (1958) も一過性の血獎 Chemo-corticoids の 増加をみている. 鈴木 (1959) は強力な可聴純音の生体 に及ぼす影響について検索し, 可聴純音がストレッサー として働き, 白血球の増加, リンパ球減少, 好酸球減少 をみとめたと述べている.

このような好酸球数の変化は, 特に Thorn が副腎皮 質機能判定の一方法として, A.C.T.H. 注射後における. 好酸球数の測定を提唱してから，検査方法の簡便さのた め, 広く実験, 臨床に用いられるようになつた。

Recant et al (1950) によると, 正常ラッテの好酸球 数は, 個体差が著しく 356 3090/ $\mathrm{mm}^{3}$ であり, 平均 $1101 / \mathrm{mm}^{3}$ といら. 又 Dumm et al (1954) の報告で は生後30〜35 日の Long-Evans 系の ラッテでは平均 $347 / \mathrm{mm}^{3}$ (39 1191/ $\mathrm{mm}^{3}$ ) である.申 (1960) は 128 . 士24.6g の雄ラッテを使用して $246 \pm 152 / \mathrm{mm}^{3}$ (84 800. $/ \mathrm{mm}^{3}$ ) であつた. 私の成績では約 $270 / \mathrm{mm}^{3}$ であつた.

以上の如く正常ラッテの好酸球数は, 個体差が非常に 大であり，かつ季節的並びに日内変動を示するのとされ ている.さらに本実験の如く, 妊娠という内的ストレス までが加はつて打り, 表 1 亿示す如く, それによる变動 も幾分認められる. しかしより大きな好酸球数の変動か ら考へて, 騒音自体が母獣に対して大なるストレッサー 
として作用したことは明らかである. 特に実験 C 群に 拉いて，その減少率が顕著であるのは，当然のことと考 ヘられる。

\section{2. 胎估について}

馶音が私達の身体に対しても，情緒の上においても， 悪影響を及ぼすことについては，既に幾多の報告がなさ れている．しかしヒトあるいは動物における胎児に及ぼ す影響については，末だあまり知られていない。

Sieve (1949) は種々の情緒的な障碍が，栄養障碍の 原因として，重要であると強調して扔り，これが妊娠母 体に加わつた場合, 当然その胎児にも栄養障碍, さらに は成長抑制を起すことが考えられる。

本実鈳成績を検討してみると，B 群では，その平均 体重は $4.2 \mathrm{~g}$ で対照の $4.3 \mathrm{~g}$ とほぼ等しい值を示すのに 対し，A 群ではその平均体重は $3.8 \mathrm{~g}$ であり， $0.4 \mathrm{~g}$ の 減少を認めた。 又死産率は A 群の $24.3 \%$ に対し, B 群 は6.7\%にすぎなかつた。しかし C 群の平均体重は 2.7 gであり，対昭のそれと比較して $1.5 \mathrm{~g}$ の差を認めた。 死産率は $59.3 \%$ であり，A 群の绿济 2.5 倍の值を示し ている.

これらの事実から，妊娠母獣に馶音刺㦸の加わつた場 合，器官分化の未だ完成していない妊娠前半期においてて は，俥度ながら発育抑制を認め，妊娠後半期では，殆ん ど影響なく，妊娠全期間中即ち第 1 日目から20日目ま でを通して騒音刺詐の加わつた群では，大なる発育遅延 のあることを知つた。

前記の如く，本実墦における母獣の好酸球数の变動か ら考えて，騒音がストレッサーとして作用したことは明 らかである. Sobin (1952) は，娃娠ラッテに太鼓の音 を聴取させて，その胎仔の心臓に奇型を生じさせたとい う.横堀 (1959) は妊娠マウスを用いて騷音刺㦸を加之 た結果，その胎仔には 90phon 以上では成長抑制作用 が，100phon 以上では催䗁型作用があつたと述べ，設 楽 (1963) は，騒音の催渏型作用には，副腎の皮質が関 与していると報告している。このように騒音によるスト レスが，胎仔畸型を起せしめることが，少数の人々によ つて述へられている，一方林（1961）は，種々の催畸型 作用が胎生期に作用して，一定の影響を及ぼしたとして 6，その極限に括いては，不妊もしくは胎生初期に沶け る还の吸収として現はれると報告していることなどか ら，本実験に乱ける如き，異常な胎生環境儿おいては， 異常仔の摘出を認められなかつた之はい文，実験 C 群 に甜りる如き，非常に死産率の高からたことから推測し
て、騷音刺钱のダイコクネズミ胎仔に対する催畸型作用 を否定することはできないと思はれる。

3. 組織学的所見について

肉眼的には，実駼群と対照を比較して，実験群は各群 共に体重面に㧊いて，発育の遅れていることは前記の如 くであるが，さらに胎仔聴器の発育程度はどのようであ るかを，組織学的に検討してみた。

対照及び実験 A，B 群の組織学的所見は殆んど差異 を認めなかつたため，対照と実験 C 群との所見を比較 してみると，外耳中耳腔形成域に打いては，両群共に未 だまつたく胎生結合織に找いて開ざされ，そこに耳小骨 原基の形成を認めるが，実験 C 群沈打いては，その原 基形成は対照群のほぼ $1 / 2$ 程度の発育しか認めない，蝸 牛においては，対照では回転下部の胎生結合織は四収さ れ，そこに前庭階，鼓室階の形成を認めるが，実験 C群 では，未だ両者の区別はできず，卵円形をした螖牛豰管 を認めるのみである.コルチ器原基沈いては，対照で は高い円柱状細胞蔡及び低い柱状細胞層に区別できる幾 分分化した像を呈するも，実験 C 群では 2〜3 層の重叠 した細胞層を認めるのみである，前庭域においては，対 昭では内リンパ腔内に丘状に隆起した平衡做を認め，そ こに平衡砂をみるも，実験 C 群では，感賞上皮の背は 低く，平衡砂はみられない。

これらの所見を葛川（1960）及び著者（1963）の報告

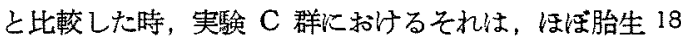
〜19 日目の所見に一致するるのであり，又特に 異常所 見は認められなかつた。

\section{結語}

妊娠したダイコクネズミに，每日 6 時間ずつ 100phon の白色騷音を聴取せしあると共に，妊娠母獣の循環好酸 球数を調べ，かつ姡娠第 21 日目に母獣を開腹して䏩仔 を摘出し，肉眼的及び胎仔聴器を組織学的に検索した。

1) 娃娠第 1 日目から10日目まで騒音刺㦸を加えた 群，及び妊娠第11日目から20日目まで騒音刺战を加えた 群では，両群を対照と比較した時，循環好酸球数の減少 率からみて，母獣に及ぼす影響は大差なく，胎仔に批け る肉眼的，組織学的所見はA群に拁いて，軽度ながら発 育幄延を認ぬだ. 即ち妊娠前半期に馶音刺㦸の加方つた 方が，発育抑制され易く，後半期に㢦音刺战の加わつた ものでは，殆んど影響のない傾向にあることを知つた。

2）妊娠第 1 日目から20日目まで騒音刺㦸の加えた 群では，強度の好酸球数の減少を㖊めると共に，胎付に おいいては強度の発育遅延を認めた。これを諸家の報告と 
比較検討してみると，ほぼ胎生 18〜19日目の胎仔所見 に一致するものである.

3）異常胎仔の婏出は認められなかつたが，しかし実 験 C 群に乱ける如く, 強度の胎仔吸収が認められるこ とから，騒音刺战の胎仔に対する催畸型作用を否定する ことはできない。

\section{參考文献}

1) Dumm, M.E. et al: A Critical Analysis of the Eosino-phile Response in Rats to ACTH and Cortisone Endocrinology 54,71, 1954.2 2) 林一郎 : 奇形の原因諭，医学のあゆみ，37，64,113, 1961。 3) 葛川繁：V.A大量投与以上る内耳奇形の胎生学的研 究, 阪市大医誌, 9, 1469, 1960.4 4) McCann, S.M. et al: Adrenalectomy and Blood Pressure of Rats subjected to Auditory Stimulation Am. J. Phisiol. $155,128,1948$. 5) 中辻清重: 音響刺戟の副肾䠗啠

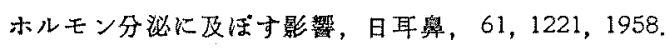

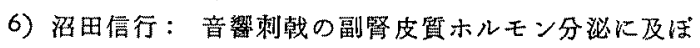

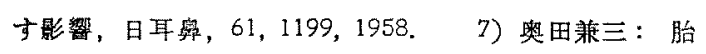
仔聴器に甜ける組織化学的研觉, 日耳鼻, 66, 1335, 1963. 8) Recant, L. et al.: Studies on the Effect of Epinephrine on the PutuitaryAdrenocortical System J.Clin. Endocri. 10, 187, 1950. 9) Siebe, B.F:
Vitamins and Hormones $\mathrm{V}$ : Emotional and Trauma. Am. J. Digest. Dis. 16, 14, 1949 . 10) 真銅宏 他：強力な可聴純音の生体に及ぼす影響，日耳鼻，57， 259, $1954 . \quad 11)$ Sobin, S.S. et al: Experimental production of Congenital cardiac lesions in the rat. Am. J. Physiol. 171, 769. 1952.112) 鈴木裕子他: 强力な可聴純音の生体に及ぼす影響について，耳畫臨， $52,116,1959$. 13) 申基洛： ラットの诸環好酸球数 に及注す2,3处琶の影響，阪市大医誌，9.5105，1960. 14）設楽敏明：騒音に上る奇形発現作用の機構炕関す る実験的研究，日耳鼻，66，533，1963。15）内海貞夫 地：音響刺戟の蛙の呼吸に及注す影響について，耳章 臨，42，33，1949. 16) 横堀国器: 䖲音刺戙による 先天性畸型発現に関する実験的研究，日耳鼻，62,2397， 1959. 17) 横山俊彦：騷音性難聴飞関する研究，日 耳鼻, 66, 675, 1963.

稆を゙䅂えるに臨み，終始御指尊，御校閲を頂 いた恩師山本馨教授に深謝致します

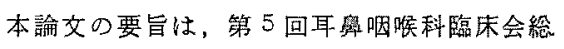
会に招いて発表した。

（原衡到着=昭和 38 ，12.27日） 